\title{
ТЕНДЕНЦІї ТРАНСФОРМАЦІЇ МІЖНАРОДНОГО БІЗНЕСУ ПІД ВПЛИВОМ ГЛОБАЛІЗАЦІї
}

\section{TRENDS IN THE TRANSFORMATION OF INTERNATIONAL BUSINESS UNDER THE INFLUENCE OF GLOBALIZATION}

\author{
Смолій Людмила Василівна \\ кандидат економічних наук, доцент, \\ Уманський національний університет садівництва \\ ORCID: https://orcid.org/0000-0002-7426-0468 \\ Осіпова Алла Анастасіївна \\ кандидат економічних наук, \\ Уманський національний університет садівництва \\ ORCID: https://orcid.org/0000-0002-5330-3676 \\ Костюк Віра Степанівна \\ кандидат економічних наук, \\ Уманський національний університет садівництва \\ ORCID: https://orcid.org/0000-0002-5311-9617

\section{Smolii Liudmyla, Osipova Alla, Kostiuk Vira Uman National University of Horticulture}

\footnotetext{
У статті розглянуто найбільш значущі тенденції, що характеризують сучасну специфіку функціонування міжнародного бізнесу Розкрито зміст трансформаційних змін, які виникають в умовах глобалізаційних тенденцій та викликів, породжених розгортанням пандемії COVID-19. Виділено новітні тенденції та вектори розвитку міжнародного бізнесу, зокрема такі, як поява нових організаційних фрорм міжнародного бізнесу, посилення ролі великих міжнародних корпорацій у міжнародному виробництві; діджиталізація та розширення залучення до бізнес-операцій циоррових технологій; активізація процесів решорингу; підвищення інноваційної активності міжнародних компаній. Виявлені тенденції окреслюють вектори подальшої еволюції бізнесу в глобальному середовищі, що дозволить сорормувати нові концепції розвитку міжнародного бізнесу з урахуванням трансформаційних процесів.

Ключові слова: міжнародний бізнес, тенденції, трансформація, глобалізація, транснаціоналізація, діджиталізація, решоринг.
}

В статье рассмотрены наиболее значимые тенденции, характеризующие современную специфику функционирования международного бизнеса Раскрыто содержание трансорормационных изменений, возникающих в условиях глобализационных тенденций и вызовов, порожденных распространением пандемии COVID-19. Выделены новые тенденции и векторы развития международного бизнеса, такие, как появление новых организационных форм международного бизнеса, усиление роли крупных международных корпораций в международном производстве; диджитализация и расширение привлечения цифровых технологий в бизнес-операции; активизация процессов решоринга; повышение инновационной активности международных компаний. Выявленные тенденции определяют векторы дальнейшей эволюции бизнеса в глобальной среде, что позволит сорормировать новые концепции развития международного бизнеса с учетом трансформационных процессов.

Ключевые слова: международный бизнес, тенденции, трансформация, глобализация, транснационализация, диджитализация, решоринг.

The evolution of the world economy in the direction of increasing globalization trends is creating transformational changes in the functioning of international business. The scale of business operations is growing rapidly, their nature is changing, there is a transformation of world production and international trade, including as a result of the spread of the COVID-19 pandemic. This necessitates the study of processes that characterize current trends in the transformation of international business, which determines the purpose of the article. To solve the tasks in the article used 
special and general research methods: economic-statistical and comparative analysis - to identify current trends in international business, diagnostics and dynamics of certain aspects of the functioning of international business entities; diagnostics of the state and dynamics of certain aspects of the functioning of international business entities; system analysis - to study the relationships between economic processes and phenomena; causal relationship, abstract-logical - in generalizing the results and formulating the conclusions of the study. As a result of research it is established that the most significant transformational tendencies reflecting modern realities of functioning of the international business are: strengthening the role of large international corporations in international production; increasing the share of enterprises that involve digital technologies in business operations; intensification of reshoring processes; increasing the innovation activity of international companies. Strengthening of processes of transnationalization of small and medium business is revealed; increasing the share of companies that use networking in order to acquire the status of global companies. The dynamics of digitalization processes of international business is considered. The most important direction in the development of digitalization of international business is the transformation of business processes based on e-commerce technologies. Among the main trends are the strengthening of the processes of return of multinational companies of their production activities from other countries to the home country of the parent company. The dynamics of growth of investments in R\&D of the largest international companies is analyzed and the tendency to increase them is revealed. The practical significance of the study is to identify the most significant trends in the transformation of international business caused by the pandemic, which makes it possible to develop a further strategy for its operation, taking into account globalization trends.

Keywords: international business, trends, transformation, globalization, transnationalization, digitalization, reshoring.

Постановка проблеми. В умовах динамічних змін, що породжуються зростаючим поглибленням глобалізаційних тенденцій, міжнародний бізнес неминуче зазнає транссрормацій. Масштаби операцій, що здійснюються в сорері міжнародного бізнесу, стрімко зростають, що підвищує роль та значення суб'єктів МБ в глобальній економіці та актуалізує дослідження постійних змін, що відбуваються в цій сфрері. Значною мірою вектори розвитку міжнародного бізнесу трансорормувались під впливом кризи, викликаної пандемією COVID-19. Вивчення сутнісних ознак, які характеризують сучасні перетворення в міжнародному бізнесі, виявлення чинників, що генерують такі зміни, набувають особливого значення для розуміння процесів, що відбуваються у світовій економіці.

Аналіз останніх досліджень і публікацій. Провідні науковці та аналітики у своїх дослідженнях все частіше звертаються до проблематики ведення міжнародного бізнесу в сучасній постіндустріальній економіці. Визначення впливу економічних, політичних, соціокультурних чинників на згаданий сектор стало предметом вивчення в працях таких вчених, як О. Лаш, Р. Коневей, В. Будкін, В. Вергун, О. Довгаль, В. Кокоріна, Е. Прушківська, В. Сідоров, А. Філіпенко та ін.

Міжнародний бізнес в науковій літературі визначається як сукупність ділових операцій, пов'язаних з перетином кордонів і рухом товарів, послуг, капіталів, працівників; трансфером технологій, інфрормації і даних, а також керівництво виконавцями [1]. В системі глобальної економіки він виконує низку функцій, серед яких: створення ланцюжків вартості; розробка інновацій; поширення знань та технологій; розвиток інноваційних мереж; формування інтернаціональних структур; забезпечення міжнародних потоків товарів, послуг, інформації, капіталу, робочої сили; інтегрування наукового потенціалу країн та консолідація світових наукових ресурсів [2].

Виділення невирішених раніше частин загальної проблеми. Наразі науковці, що досліджують питання розвитку міжнародного бізнесу, не мають єдиного підходу до визначення перспектив формування середовища функціонування суб'єктів міжнародної підприємницької діяльності. Виокремлюється дві точки зору: частина дослідників дотримується думки, що розвиток бізнесу відбуватиметься в інсрорматизованому суспільстві $з$ пріоритетом інтелекту і знань під впливом глобалізації; інші мають бачення щодо домінування екологічної і політико-економічної складових [3]. Виділення основних тенденцій, що детально характеризують процеси транссрормації міжнародного бізнесу внаслідок поглиблення глобалізації, дозволяє більш чітко виробити бачення перспектив його розвитку та вчасно сорормувати стратегії подальшого функціонування.

Мета статті - дослідження векторів трансфрормації міжнародного бізнесу під впливом глобалізаційних тенденцій.

Виклад основного матеріалу дослідження. Основу процесів глобалізації, що зазнали модифрікації в результаті впливу пандемії коронавірусу, становить зростання ступеня взаємозалежності національних економік та посилення взаємодії суб'єктів з різних 
частин світу. Внаслідок цих процесів у світі відбувається формування єдиного багаторівневого ринку та виробничого сектору. Це створює нові умови діяльності для суб'єктів міжнародного бізнесу, що змушує їх адаптуватись до швидких змін у середовищі фрункціонування, виявляти гнучкість для збереження конкурентних позицій при здійсненні бізнесоперацій, вчасно і адекватно реагувати на виклики, активно інтегруватись в світові економічні процеси. Під впливом цих чинників міжнародний бізнес видозмінюється і набуває глобального характеру.

Дослідження транссрормаційних змін, що відбуваються в міжнародному бізнесі на тлі поглиблення глобалізаційних процесів, дозволило виокремити декілька основних тенденцій, які можна виділити як найбільш значущі.

1. Поява нових організаційних форм міжнародного бізнесу та посилення ролі великих міжнародних корпорацій у міжнародному виробництві.

Становлення транснаціонального бізнесу - це відносно не нове явище в світовій глобалізованій економіці, однак наразі змінюються фрорми та механізми взаємодії та взаємовпливу такий компаній, змінюються пріоритети інвестування, стратегії взаємодії на світовому ринку. Однією 3 ключових рис $€$ зростання концентрації орінансових ресурсів в межах ТНК та збільшення масштабів їх діяльності. Це призводить до того, що часто доходи таких мегакорпорацій перевищують ВВП окремих країн, що посилює контроль над обсягами грошової маси у світовій фрінансовій системі (табл. 1).

Слід зазначити, що на сьогодні прослідковується тенденція до збільшення ступеня транснаціоналізації малого і середнього бізнесу, i, згідно з прогнозами, вона буде посилюватись в найближчі 20-30 років. В результаті транснаціоналізація необов'язково передбачатиме наявність великомасштабного виробництва, а пов'язуватиметься 3 формуванням глобальної конкурентоспроможності компаніями різних масштабів. Ще однією особливістю стає утворення структур, які не здійснюють прямих іноземних інвестицій, набуваючи при цьому статусу «глобальних» компаній. Реалізується це за рахунок використання моделі глобального бізнесу під назвою «нетчайзинг» (netchising), яка базується на використання мережі Інтернет для закупівель, продажів і підтримки відносин зі споживачами та забез-

Порівняння річних обсягів доходу транснаціональних компаній

Таблиця 1 і ВВП окремих країн світу в 2020 р.

\begin{tabular}{|c|c|c|c|c|}
\hline $\begin{array}{c}\text { Tрансна- } \\
\text { ціональна } \\
\text { корпорація }\end{array}$ & Галузь & $\begin{array}{l}\text { Доходи, } \\
\text { млрд дол }\end{array}$ & $\begin{array}{c}\text { Держава, } \\
\text { співвимірна Тнк } \\
\text { по розміру ВВП }\end{array}$ & $\begin{array}{c}\text { ВВП за ПкС, } \\
\text { млрд дол }\end{array}$ \\
\hline $\begin{array}{l}\text { Sinopec } \\
\text { Group }\end{array}$ & Нафртопереробка & 407,0 & Ірак & 401,0 \\
\hline Amazon & $\begin{array}{l}\text { Iнтернет-послуги i } \\
\text { роздрібна торгівля }\end{array}$ & 347,9 & Данія & 343,0 \\
\hline $\mathrm{BP}$ & Нафртопереробка & 282,6 & М'янма & 279,0 \\
\hline Apple & Електроніка & 260,1 & Узбекистан & 253,0 \\
\hline Alphabet & $\begin{array}{l}\text { Інтернет-послуги і } \\
\text { роздрібна торгівля }\end{array}$ & 171,7 & Болгарія & 165,0 \\
\hline SAIC Motor & $\begin{array}{l}\text { Автомобільна } \\
\text { промисловість }\end{array}$ & 122,1 & Туніс & 120,0 \\
\hline Bosch & Інженерія & 87,0 & Словенія & 81,3 \\
\hline Facebook & Інтерактивні 3МІ & 79,0 & Ліван & 78,9 \\
\hline Sony & Електроніка & 76,9 & Люксембург & 73,9 \\
\hline PepsiCo & $\begin{array}{c}\text { Харчова } \\
\text { промисловість }\end{array}$ & 68,6 & Замбія & 63,1 \\
\hline $\begin{array}{l}\text { Vodafone } \\
\text { Group }\end{array}$ & Телекомунікації & 49,8 & $\begin{array}{c}\text { Боснія i } \\
\text { Герцоговина }\end{array}$ & 49,3 \\
\hline Tata Motors & $\begin{array}{l}\text { Автомобільна } \\
\text { промисловість }\end{array}$ & 37,2 & Гвінея & 36,4 \\
\hline Wistron & Електроніка & 28,4 & Палестина & 27,5 \\
\hline
\end{tabular}


печує компаніям значні переваги в порівнянні з традиційним експортом або прямими зарубіжними інвестиціями [5, с. 120].

Змінюються також і тенденції світового виробництва, що визначатимуть розташування та масштаби міжнародного бізнесу. Після стрімкого зростання міжнародного виробництва, обумовленого політикою лібералізації та технологіями, темпи його починають сповільнюватись. Це спричинено поверненням протекціоністських тенденцій, поступовим поверненням норми прибутку на прямі іноземні інвестиції та скороченням капіталомісткості іноземного виробництва завдяки використанню нових технологій. В Доповіді про світові інвестиції (ЮНКТАД) [6] наводиться перелік тенденцій, які в майбутньому визначатимуть напрями розвитку міжнародного виробництва (табл. 2).

Новітні тенденції свідчать про відхід від парадигми інвестування, спрямованого на використання фракторів виробництва та дешевої робочої сили, до залучення інвестицій в розвиток інфраструктури та послуг, а також в «зелену» та «синю» економіки. Це передбачає створення нових секторів в міжнародному бізнесі - розробка та використання відновлювальних джерел енергії , охорона здоров'я та ін.

2. Діджиталізація міжнародного бізнесу.

В ссрері міжнародного бізнесу посилюється тенденція до збільшення частки підприємств, що залучають до бізнес-операцій цифрові технології. Третина діючих міжнародних компаній виділяють значні ресурси на цифровізацію власних процесів. $70 \%$ компаній, які впроваджують цисррові технології, досягають більш високих темпів зростання продуктивності, ніж звичайна фрірма [7.]. На частку 10\% традиційних компаній з найбільшими цифровими доходами припадає до 80\% цифрового доходу, що продукується в їхньому секторі; $60 \%$ - у сорері професійних послуг; 77\% у copepi high-tech послуг та автомобілебудування; 93\% - у ссрері роздрібної торгівлі; до 90\% - у сорері засобів масової інфрормації та телекомунікацій (рис. 1) [8].

До основних цифрових технологій, що відбражають цифрову трансформацію міжнародного бізнесу належить розвиток та використання штучного інтелекту, інтернет речей, хмарних технологій, цифррового проектування і моделювання технологічних процесів, адаптивних технологій 3D, електронного документообігу та урядування, цисррових технологій у сорері фрінансових (FinTech) та страхових (InsurTech) послуг [9].

Одним 3 найбільш вагомих напрямів розвитку цифровізації міжнародного бізнесу $€$ трансорормація бізнес-процесів на основі технологій електронної комерції. Найбільша статистична платорорма Statista [10] наводить дані, за якими світове зростання роздрібних

Мегатенденції, які визначатимуть майбутнє міжнародного виробництва

\begin{tabular}{|c|c|c|}
\hline Сорера дії & Тенденції & Ключові елементи \\
\hline Технології & $\begin{array}{l}\text { Новітня робототехніка і } \\
\text { штучний інтелект } \\
\text { Цифровізація ланцюга } \\
\text { постачання } \\
\text { Технології 3D друку }\end{array}$ & $\begin{array}{l}\text { Промислова автоматизація, системи } \\
\text { штучного інтелекту } \\
\text { Платфрорми, хмарні технології, } \\
\text { інтернет речей, блокчейн } \\
\text { Розподілене виробництво, } \\
\text { масова індивідуальна адаптація і } \\
\text { диференціація виробництва }\end{array}$ \\
\hline $\begin{array}{l}\text { Політика і економічне } \\
\text { управління }\end{array}$ & $\begin{array}{l}\text { Посилення державного } \\
\text { втручання в політиці держави } \\
\text { Посилення протекціонізму в } \\
\text { торгівлі та інвестиціях } \\
\text { Посилення регіонального, } \\
\text { двостороннього і разового } \\
\text { економічного співробітництва } \\
\end{array}$ & $\begin{array}{l}\text { Промислова політика, } \\
\text { антимонопольна політика, податкова } \\
\text { політика } \\
\text { Тарифи і нетарисрні заходи, захист } \\
\text { стратегічних і чутливих галузей } \\
\text { Торговельні угоди між окремими } \\
\text { групами і по загальних питаннях } \\
\end{array}$ \\
\hline Стійкість & $\begin{array}{l}\text { Заходи політики і } \\
\text { регулювання, спрямовані на } \\
\text { досягнення стійкості } \\
\text { Зміни в товарах і технологіях } \\
\text { під впливом ринку } \\
\text { Вплив на ффізичні ланцюги } \\
\text { постачання }\end{array}$ & $\begin{array}{l}\text { Основні «зелені» плани } \\
\text { Підвищення репутаційних ризиків і } \\
\text { попиту на товари і послуги, вироблені } \\
\text { на умовах стійкості } \\
\text { Заходи із забезпечення стійкості } \\
\text { ланцюгів постачання, зміна джерел } \\
\text { сільськогосподарських ресурсів }\end{array}$ \\
\hline
\end{tabular}




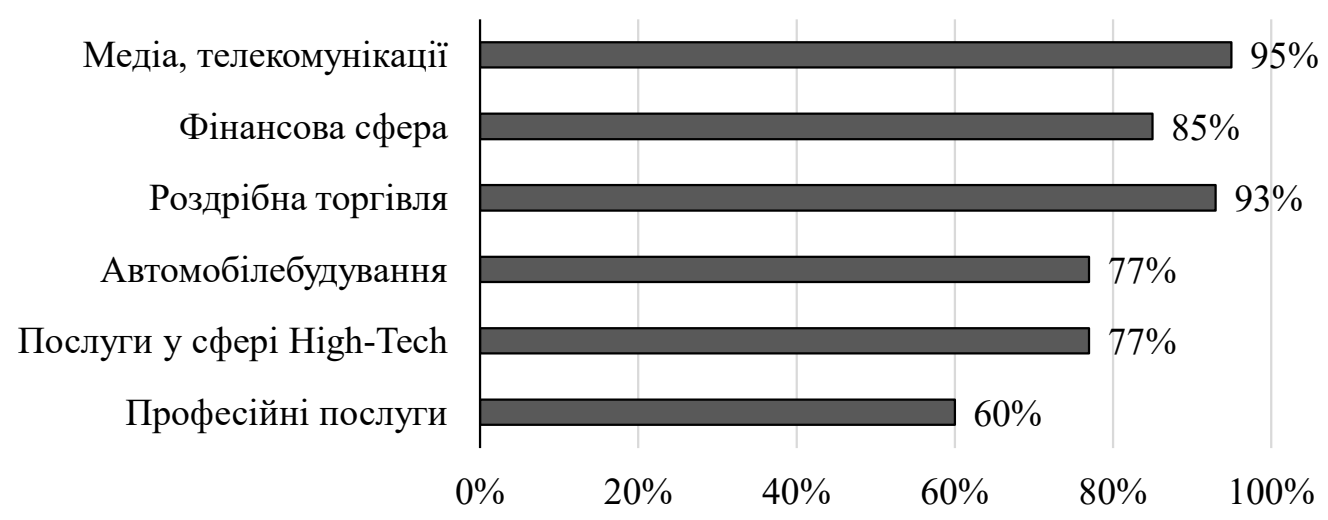

Рис. 1. Сфери, що забезпечують найбільший цифровий дохід міжнародним компаніям (\% цифрового доходу в секторі, що припадає на 10\% компаній з найбільшими цифровими доходами)

Джерело: [8]

продажів електронної комерції в 2020 р. становить $25,7 \%$, а частка електронної комерції у загальному обсязі глобальних роздрібних продажі складає 18\%. За прогнозами, найбільші компанії, що використовують технології електронної комерції, до кінця 2021 року збільшать свої доходи на 39\% порівняно 3 2019 роком. Частка роздрібної торгівлі з використанням технологій електронної комерції в розвинутих країнах світу становить до 50\% ВВП (рис. 2).

Стрімкий розвиток такого потужного сегмента міжнародного бізнесу, як електронна торгівля, дає поштовх для фрормування та розвитку інших сорер, які мають приналежність до електронної комерції: електронний обмін інфоормацією (Electronis Data Interchange, EDI), електронний рух капіталу (Electronic Funds Transfer, EFS), електронні гроші (E-Cash), електронний маркетинг (E-Marketing), електронний банкінг (E-Banking), електронні страхові послуги (E-Insurance) тощо [12, с. 5].

\section{3. Активізація процесів решорингу.}

Описані вище тенденції діджиталізації породжують передумови для решорингу повернення транснаціональними компаніями своєї виробничої діяльності 3 інших країн в країну базування материнської компанії. Ці процеси викликають активні дискусії щодо їх наслідків для міжнародного бізнесу та

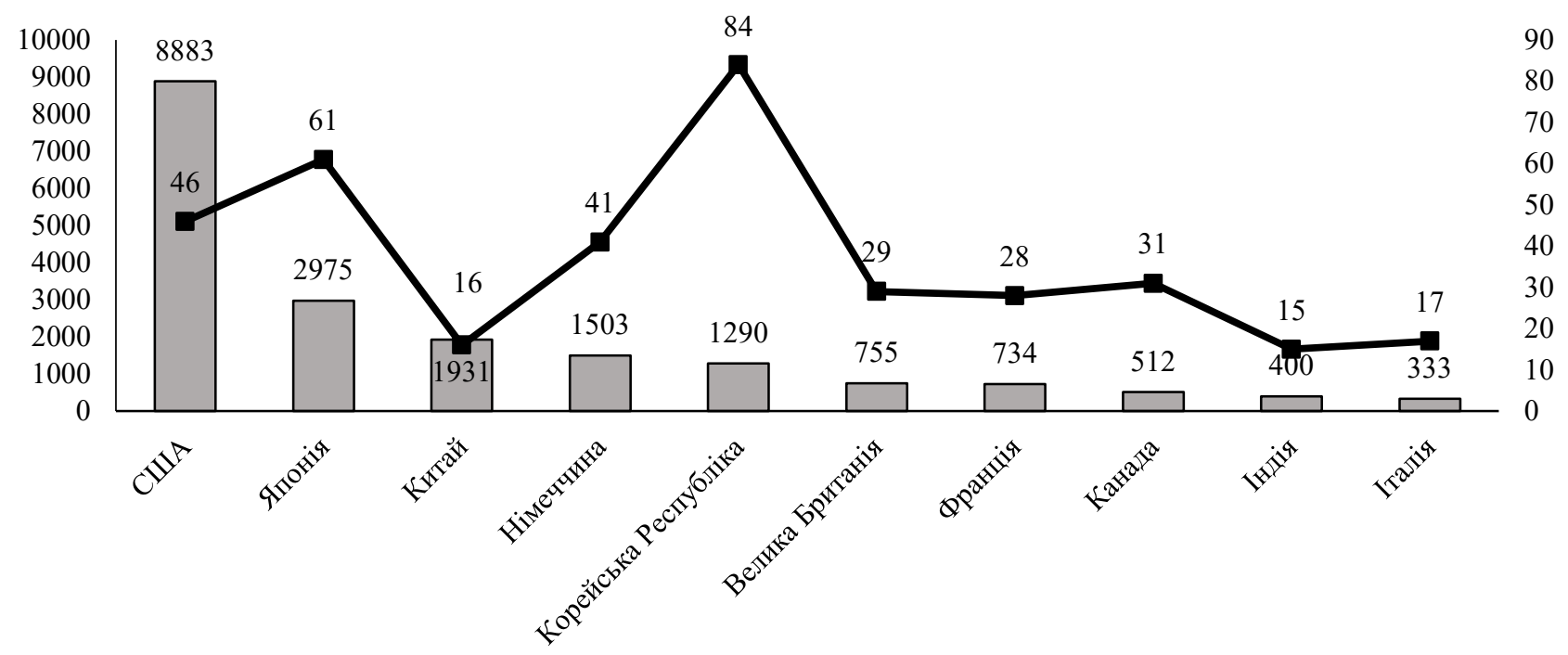

Обсяг електронних продажів, млрд дол. США $\boldsymbol{-}$ Обсяг електронних продажів у \% до ВВП

Рис. 2. Показники обсягів електронної комерції в окремих країнах у 2019 р. 
Інвестиції в НДДКР провідних міжнародних компаній у 2020 р.

Таблиця 3

\begin{tabular}{|l|c|c|}
\hline \multicolumn{1}{|c|}{ Назва компанії } & Обсяг інвестицій, млн євро & $\begin{array}{c}\text { Приріст інвестицій } \\
\text { у порівнянні 3 2015 р., \% }\end{array}$ \\
\hline Alphabet & 23160,1 & 109,5 \\
\hline Microsoft & 17152,4 & 55,8 \\
\hline Apple & 14435,6 & 94,8 \\
\hline Facebook & 12106,1 & 173,7 \\
\hline Intel & 11894,3 & 6,8 \\
\hline Johnson \& Johnson & 10107,7 & 21,6 \\
\hline Merck Us & 8234,8 & 27,9 \\
\hline
\end{tabular}

Джерело: розраховано автором за даними [14]

глобальної економіки в цілому, однак достеменно можна стверджувати, що решоринг має значний вплив на трансорормацію міжнародного бізнесу в частині збільшення кількості робочих місць в країнах походження компаній (як правило, розвинутих країнах) та згортання виробництва внаслідок його перенесення у країнах, що розвиваються. Поряд 3 поширенням діджиталізації та роботизації виробництва, чинниками, що сприяють активізації решорингу, є: зміна структури витрат у країнах, що розвиваються, потенційні загрози інтелектуальній власності, прагнення до отримання більшої гнучкості через близькість до споживчих ринків, вразливість до стихійних лих та політичних подій [13].

\section{4. Підвищення інноваційної активності міжнародних компаній}

На сьогодні основним джерелом конкурентних переваг стає здатність до інновацій. Структура витрат найбільших транснаціональних компаній демонструє зростання інвестицій в НДДКР (табл. 3).

Аналіз рейтингів міжнародних корпорацій за витратами на НДДКР засвідчує приналежність лідерів інвестування цієї сорери до таких галузей, як виробництво програмного забезпечення та надання інфрормаційних послуг, автомобілебудування, фрармацевтики, електроніки. Для утримання лідерських позицій інноваційні можливості слід постійно нарощувати, а це вимагає формування нових інноваційних стратегій та перетворення інноваційної діяльності на системний процес.

Висновки. Підсумовуючи, слід зазначити, що транссрормація міжнародного бізнесу в умовах глобалізації - це надзвичайно складний та багатоаспектний процес. Виділені нами тенденції поява нових організаційних фрорм міжнародного бізнесу; посилення ролі великих міжнародних корпорацій у міжнародному виробництві; активізація процесів діджиталізації та решорингу; підвищення інноваційної активності міжнародних компаній, - становлять лише частину тих характеристик, що визначатимуть подальшу еволюцію бізнесу в глобальному середовищі. Однак уже сьогодні розуміння інтенсивності впливу цих змін на подальші перспективи функціонування компаній, що провадять міжнародну діяльність, дозволить реалізувати нові концепції провадження бізнесу на якісно новому етапі розвитку глобалізованої економіки.

\section{СПИСОК ВИКОРИСТАНИХ ДЖЕРЕЛ:}

1. Кокоріна В.І. Трансформація форм міжнародного бізнесу в умовах глобального інноваційного суперництва. Міжнародна економічна політика. 2012. Ч. 1. С. 122-129.

2. Поляков М.В. Особливості розвитку міжнародного бізнесу в умовах становлення глобальної економіки знань. Економічний простір. 2017. № 121. C. 47-57. URL: http://nbuv.gov.ua/UJRN/ecpros_2017_121_6

3. Кокоріна В.І. Консолідація міжнародного бізнесу в епоху глобалізації постіндустріальної цивілізації. URL: http://lib.khnu.km.ua/konfer_HNU/2019/index.pdf

4. Прусова В., Горбачева В. Транснациональные корпорации развивающихся стран, как эволюционная перемена в мировой экономике. Экономика и управление. 2021. № 2. URL: https://www.adi-madi.ru/madi/ article/view/1007/pdf_587

5. Прушківська Е.В., Третьякова К.О. Основи розвитку новітніх форм міжнародного бізнесу в умовах глобалізації. Економічний вісник Національного гірничого університету. 2018. № 2. С. 119-125. URL: http://nbuv.gov.ua/UJRN/evngu_2018_2_15.

6. World Investment Report 2021. UNCTAD. URL: https://unctad.org/webflyer/world-investment-report-20217 
7. Twenty-five years of digitization: Ten insights intohow to play it right. McKinsey Global Institute. 2019. P. 1-12.

8. The $90 \%$ success recipe: How digital and analytics can help commercial transformations beat the odds and the market. McKinsey Global Institute. 2021. URL: https://www.mckinsey.com/business-functions/marketing-andsales/our-insights/the-90-percent-success-recipe

9. Любохинець Л.С. Впровадження стратегії digital-трансформації в сучасному бізнес-середовищі. Imperatives of development of civil society in promoting national competitiveness: 1st international research and practice conference (Batumi, Georgia, 13th-14th December 2018). 2018. P. 41-44.

10. Coppola D. Statistics and facts about global e-commerce. 2021. URL: https://www.statista.com/topics/871/ online-shopping/\#dossier-chapter1

11.UNCTAD Digital Report. New York : United Nations Publikations, 2019. 194 p.

12. Ануфрієва О.Л. Електронна комерція в системі цифрової економіки. Науковий вісник УМО. Серія : Економіка та управління. 2017. Вип. 3. С. 1-12.

13. Ellram L., Tate W., Petersen K. Offshoring and Reshoring: An Update on the Manufacturing Location Decision. Journal of Supply Chain Management. 2013. Vol. 49. № 2. P. 101-132.

14. World top 2500 R\&D investors. Edition 2020. The 2020 EU Industrial R\&D Investment Scoreboard. URL: https://iri.jrc.ec.europa.eu/scoreboard/2020-eu-industrial-rd-investment-scoreboard

\section{REFERENCES:}

1. Kokorina, V.I. (2012) Transformatsiia form mizhnarodnoho biznesu v umovakh hlobalnoho innovatsiinoho supernytstva [Transformation of forms of international business in the conditions of global innovation rivalry]. Mizhnarodna ekonomichna polityka - International economic policy, 1, 122-129. (in Ukrainian)

2. Polyakov, M.V. (2017) Osoblyvosti rozvytku mizhnarodnoho biznesu v umovakh stanovlennia hlobalnoi ekonomiky znan [Peculiarities of international business development in the conditions of formation of global knowledge economy]. Ekonomichnyi prostir - Economic space, 121, 47-57. Retrieved from: http://nbuv.gov.ua/UJRN/ ecpros_2017_121_6 (in Ukrainian)

3. Kokorina, V.I. (2019) Konsolidatsiia mizhnarodnoho biznesu v epokhu hlobalizatsii postindustrialnoi tsyvilizatsii [Consolidation of international business in the era of globalization of post-industrial civilization]. Retrieved from: http://lib.khnu.km.ua/konfer_HNU/2019/index.pdf (in Ukrainian)

4. Prusova, V., \& Gorbacheva, V. (2021) Transnatsyonalnye korporatsyy razvyvaiushchykhsia stran, kak evoliutsyonnaia peremena $v$ myrovoi ekonomyke [Transnational corporations of developing countries as an evolutionary change in the world economy]. Ekonomyka y upravlenye - Economics and Management, 2. Retrieved from: https://www.adi-madi.ru/madi/article/view/1007/pdf_587 (in Russian)

5. Prushkivska, E.V., \& Tretyakova, K.O. (2018) Osnovy rozvytku novitnikh form mizhnarodnoho biznesu v umovakh hlobalizatsii [Fundamentals of development of the newest forms of international business in the conditions of globalization]. Ekonomichnyi visnyk Natsionalnoho hirnychoho universytetu - Economic Bulletin of the National Mining University, 2, 119-125. Retrieved from: http://nbuv.gov.ua/UJRN/evngu_2018_2_15 (in Ukrainian)

6. World Investment Report 2021. UNCTAD. Retrieved from: https://unctad.org/webflyer/world-investment-report-20217

7. Twenty-five years of digitization: Ten insights intohow to play it right (2019) McKinsey Global Institute, 1-12.

8. The $90 \%$ success recipe: How digital and analytics can help commercial transformations beat the odds and the market (2021) McKinsey Global Institute. Retrieved from: https://www.mckinsey.com/business-functions/marketing-and-sales/our-insights/the-90-percent-success-recipe

9. Lyubokhinets, L.S. (2018) Vprovadzhennia stratehii digital-transformatsii v suchasnomu biznes-seredovyshchi [Implementation of digital transformation strategy in the modern business environment]. Imperatives of development of civil society in promoting national competitiveness: 1st international research and practice conference (Batumi, Georgia, December $13^{\text {th }}-14^{\text {th }}, 2018$ ), pp. 41-44. (in Ukrainian)

10. Coppola, D. (2021) Statistics and facts about global e-commerce. Retrieved from: https://www.statista.com/ topics/871/online-shopping/\#dossier-chapter1

11.UNCTAD Digital Report (2019). New York: United Nations Publikations, 194 p.

12. Anufrieva, O.L. (2017) Elektronna komertsiia v systemi tsyfrovoi ekonomiky [E-commerce in the digital economy]. Naukovyi visnyk UMO. Seriia: Ekonomika ta upravlinnia - Scientific Bulletin of UMO. Series: Economics and Management, 3, 1-12. (in Ukrainian)

13. Ellram, L., Tate, W., \& Petersen, K. (2013) Offshoring and Reshoring: An Update on the Manufacturing Location Decision. Journal of Supply Chain Management, 2, vol. 49, 101-132.

14. World top 2500 R\&D investors. Edition 2020. The 2020 EU Industrial R\&D Investment Scoreboard. Retrieved from: https://iri.jrc.ec.europa.eu/scoreboard/2020-eu-industrial-rd-investment-scoreboard 